Article

\title{
Ripening Characteristics and Pigment Changes in Russeted Pear Fruit in Response to Ethylene and 1-MCP
}

\author{
Nongluk Charoenchongsuk ${ }^{1}$, Daiki Matsumoto ${ }^{1}$, Akihiro Itai ${ }^{2}$ and Hideki Murayama ${ }^{1, *}$ \\ 1 Faculty of Agriculture, Yamagata University, Wakabamachi 1-23, Tsuruoka 997-8555, Japan; \\ nongluk.cha@gmail.com (N.C.); daiki@tds1.tr.yamagata-u.ac.jp (D.M.) \\ 2 Graduate School of Life and Environmental Sciences, Kyoto Prefectural University, Kitaina-Yazuma Oji 74, \\ Seika Town, Soraku-gun, Kyoto 619-0244, Japan; itai@kpu.ac.jp \\ * Correspondence: mhideki@tds1.tr.yamagata-u.ac.jp; Tel.: +81-235-28-2887
}

Received: 2 August 2018; Accepted: 24 August 2018; Published: 28 August 2018

\begin{abstract}
Ripening characteristics and pigment changes were investigated in 'La France', 'Gorham', and their russeted sports 'Gold La France' and 'Grand Champion' pears. Fruit were harvested at commercial maturity and ripened at $20^{\circ} \mathrm{C}$. In all cultivars, fruit softening was concomitant with a burst in ethylene production. Interestingly, such changes were delayed in russet pear when compared with their wild-types. Chlorophyll level in russet pear at harvest was the same as in the wild-type. In 'Gorham' and 'Grand Champion' pears, its level rapidly decreased during ripening. Ethylene or 1-methylcyclopropene (1-MCP) did not affect the color and pigments in 'La France' and 'Gold La France' pears. In contrast, in 'Gorham' and 'Grand Champion' pears, chlorophyll degradation was suppressed by 1-MCP treatment, but not completely. These results suggested that chlorophyll degradation was regulated by both ethylene-dependent and ethylene-independent means. The influence of ethylene on the expression of chlorophyll-degradation-related genes seemed to be similar in both russet and wild-type. The Stay green-1 gene was stimulated by ethylene and suppressed by 1-MCP treatment. In contrast, little effect of ethylene or 1-MCP was observed on chlorophyllase 1, pheophytinase, pheophorbide a oxygenase, and NYC1-like genes.
\end{abstract}

Keywords: chlorophylls; ethylene; 1-methylcycropropene; russet pear

\section{Introduction}

The amounts and types of pigments in plant tissues are responsible for the colors of plants. In European pear (Pyrus communis L.) fruit, there are three different colors expressed at the mature stage; green, red, and brown. Green pears, including 'Bartlett' and 'Doyenne du Comice', usually turn yellow during ripening. The development of yellow color in green pears results from the masking of carotenoids with chlorophyll at harvest, as well as unmasking by chlorophyll degradation, as reported in the fruit and/or leaves of various plants, including pears [1,2]. Among green pears, 'La France' accounts for $\sim 70 \%$ of the pear production in Japan and this cultivar remains green even when fully ripe [3].

The brown pear is a well-known russeted pear. Terrestrial plants have evolved lipophilic barriers that protect against dehydration, physical damage, pathogens, and diseases. Plant primary organs, such as young stems and leaves, are protected by the cuticle, a lipophilic extracellular polymer membrane composed of cutin and waxes. Secondary (mature) stems and roots, tubers, and healing tissues are protected by cork mainly composed of suberin [4]. Suberin is a complex polymer with both aliphatic and aromatic domains, as well as an associated wax [5]. The suberized exocarp of potato (Solanum tuberosum) [6] and the bark of cork tree (Quercus suber) are the best characterized examples. 
Suberized tissue is also observed in the exocarp of fruits such as apples and pears and is referred to as fruit russet.

Studies on pear russet have a long history dating back to the early 20th century. Kikuti [7] showed that russeted skin was dominant over green skin in Japanese pear (P. pyrifolia Nakai) based on cross hybridization experiments. The random amplification of polymorphic DNA marker linked to fruit skin color in Japanese pear was then identified [8]. At this time, studies on russet in Japanese pear were mostly focused on fruit breeding. Very recently, the molecular mechanisms of russet formation have been studied in sand pear (P. pyrifolia Nakai) [9,10]. Putative cinnamoyl-CoA reductase (CCR), cinnamyl alcohol dehydrogenase (CAD), and peroxidase (POD), which are involved in lignin biosynthesis, were suggested as candidates involved in russet formation [9]. Russet has also been studied in the European pear. The extent of russet development depends on the cultivar. Some cultivars are partially covered with russet, while others are fully russeted. The coverage area of russet can differ even within the same cultivar [11]. The amount of russet can also be affected by various factors including temperature or humidity [11,12], disease or pest damage [13,14], and agrochemical applications such as insecticides, fungicides, and growth regulators $[15,16]$. These studies have been performed from the viewpoint of reducing the extent of russet because russeted fruit often have reduced market value. However, the effects of russet on fruit ripening and the biological changes in russet pears remain unclear.

Ethylene is required for the ripening of many fruits. In particular, climacteric fruit produces ethylene and increase their respiration rate at the onset of ripening [17]. Exposure to ethylene is known to accelerate ripening, increase fruit softening even in cold storage, and decrease the quality and storage life of many fruits and vegetables. 1-Methylcyclopropene (1-MCP) is an inhibitor of ethylene receptors that retards ethylene-dependent responses such as ripening, senescence, and physiological disorders $[18,19]$. There is an excellent review of the use of $1-\mathrm{MCP}$ on fruits and vegetables by Watkins [20]. In pear fruit, 1-MCP also extends storage quality and is especially effective for reducing the incidence of superficial scald [21]. However, initiating ripening capacity of the 1-MCP treated fruit following cold storage is a challenge [22]. Recently, Zhi and Dong [23] provided the preliminary basis for commercial application of 1-MCP in over-mature pears and demonstrated its potential for maintaining fruit quality and reducing the incidence of superficial scald.

Exogenous ethylene also stimulated chlorophyll degradation in many fruits and vegetables including European pears such as 'Bartlett' [24] and Chinese pears such as 'Yali' (P. bretschneideri Rehd.) [25]. In contrast, the application of 1-MCP suppressed chlorophyll degradation in the Chinese pears 'Emerald' (P. bretschneideri Rehd.) and 'Jingbai' (P. ussuriensis Maxim.) [26]. Despite the importance of skin color for fruit quality, there is little information on the biological changes associated with russet pears. In the present study, we compared the ripening of russet pears with that of green types. We focused primarily on pigments and chlorophyll degradation-related genes. Thus, we used four cultivars with different characteristic pigment changes during ripening. 'Gorham' and 'La France' cultivars are green pear cultivars where 'La France' pears remain green even after ripening. Their bud sports 'Grand Champion' and 'Gold La France' are russet types, whose fruit are fully covered with russet. In addition, both types of fruit were treated with ethylene or 1-methylcyclopropene (1-MCP) to study the role of ethylene on fruit ripening and color changes.

\section{Materials and Methods}

\subsection{Plant Materials}

The green pears (Pyrus communis L. cv. 'La France' and 'Gorham') and their russeted sports ('Gold La France' and 'Grand Champion') were harvested at the mature green stage from a commercial orchard in Yamagata Prefecture, Japan. Fruit were selected with uniform color, shape, and without damage or visual defects, and were divided into three groups. The first group was used as a control, and the other two groups were treated in 200-L acryl boxes with $100 \mu \mathrm{L} / \mathrm{L}$ of ethylene or $1 \mu \mathrm{L} / \mathrm{L}$ of 
1-MCP, respectively, at ambient temperatures for $24 \mathrm{~h}$. All fruit were held at $20{ }^{\circ} \mathrm{C}$ for ripening. Five 'La France' and 'Gold La France' pears were sampled every 6 days from the control and 1-MCP-treated groups and sampled every 3 days if ethylene-treated, during ripening. 'Gorham' and 'Grand Champion' pears were sampled every 4 days from the control and 1-MCP-treated groups and sampled every 2 days from the ethylene-treated group.

\subsection{Measurement of Ethylene Production and Flesh Firmness}

Individual fruit were placed in 1.5-L glass desiccators that were flushed with air and sealed for $1 \mathrm{~h}$. Gas samples $(1 \mathrm{~mL})$ were withdrawn using a syringe and injected into a gas chromatograph (model GC-8A, Shimadzu Co., Kyoto, Japan) fitted with an activated alumina column and a flame ionization detector. Flesh firmness was determined on the opposite sides of each pear using a rheometer (Sun Scientific, Tokyo, Japan) with an $8 \mathrm{~mm}$ plunger.

\subsection{Pigment Analysis}

Peel discs of each fruit were prepared using a $20 \mathrm{~mm}$ diameter cork borer. Two discs from each fruit were extracted with $80 \%$ acetone. The amounts of chlorophyll and carotenoid were calculated according to Arnon's equations [27]. The results were expressed as $\mathrm{mg} \cdot \mathrm{cm}^{-2}$.

\subsection{RNA Isolation and Quantitative Polymerase Chain Reaction ( $q$ RT-PCR)}

Total RNA samples were isolated from fruit peel using the RNeasy Mini Kit (Takara Bio, Shiga, Japan). First-strand cDNA was synthesized from the total RNA using Primescript ${ }^{\mathrm{TM}}$ II RTase (Takara Bio, Shiga, Japan), following the manufacturer's instructions. Quantitative PCR mixtures were prepared using the FastStart Essential DNA Green Master Kit (Takara Bio, Shiga, Japan) on a LightCycler Nano System (Roche Diagnostics, Indianapolis, IN, USA). Primer sequences for each gene were designed based on the sequences of Pyrus bretschneideri published in the NCBI database (https://www.ncbi.nlm.nih.gov/). EF1- $\alpha$ was used as the reference gene. The cycles were performed as follows: a denaturation step at $95^{\circ} \mathrm{C}$ for $5 \mathrm{~min}$ followed by 45 cycles of $95^{\circ} \mathrm{C}$ for $10 \mathrm{~s}, 60^{\circ} \mathrm{C}$ for $10 \mathrm{~s}$ and $72{ }^{\circ} \mathrm{C}$ for $15 \mathrm{~s}$. The qRT-PCR analysis was performed according to LightCycler Nano Software Version 1.0.3 and the relative expression levels of the target genes were calculated following the $2^{-\Delta \Delta C T}$ formula with six replications [28].

\subsection{Statistical Analyses}

Experiments were performed according to a completely randomized design. All data were analyzed using one-way ANOVA using the SAS software package (SAS Institute Inc., Cary, NC, USA). Significant differences in the data were determined by Tukey's tests on each treatment in all fruit cultivars.

\section{Results}

\subsection{Ethylene Production and Fruit Softening}

In 'Gorham' pears, ethylene production of the control fruit increased after day four (Figure 1). Ethylene treatment did not significantly affect ethylene production. In 'Grand Champion' pears, ethylene treatment promoted ethylene production, and fruit treated with ethylene produced more ethylene than did the control fruit. Ethylene production was suppressed by 1-MCP treatment throughout the experimental periods in both 'Gorham' and 'Grand Champion' pears. Fruit softening was stimulated by ethylene treatment and suppressed by 1-MCP treatment in both cultivars. However, this suppression was not perfect. Thus, flesh firmness gradually decreased after day four, even in fruit treated with 1-MCP.

In 'La France' and 'Gold La France' pears, ethylene production was stimulated by ethylene treatment and suppressed by 1-MCP treatment (Figure 2). Flesh firmness of 'La France' and 'Gold La 
France' fruits treated with ethylene rapidly decreased after days three and six, respectively. In contrast, flesh firmness of fruit treated with 1-MCP did not change during ripening in these cultivars.

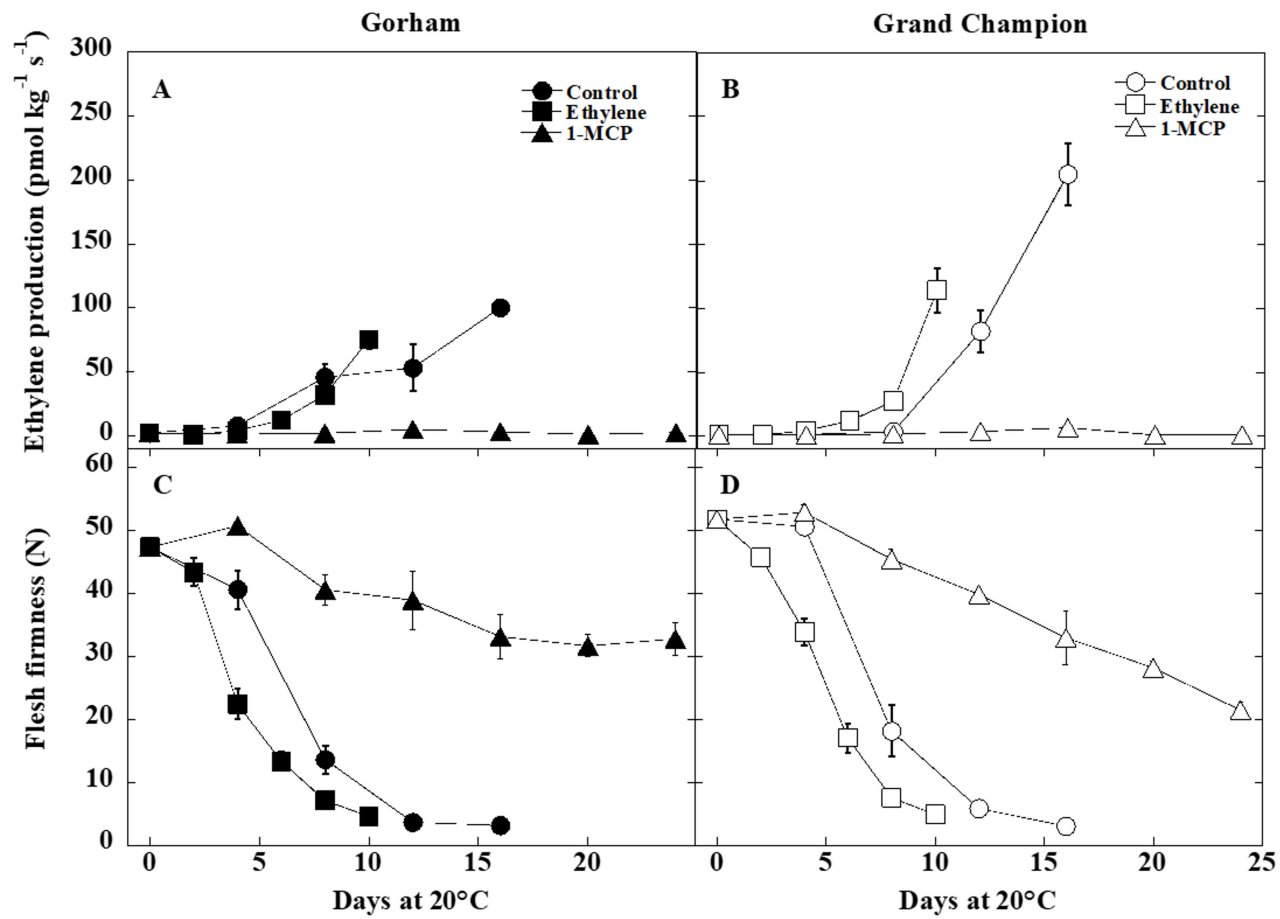

Figure 1. Changes in ethylene production $(\mathbf{A}, \mathbf{B})$ and flesh firmness $(\mathbf{C}, \mathbf{D})$ of 'Gorham' and 'Grand Champion' fruit treated with ethylene and 1-methylcyclopropene (1-MCP) during ripening at $20^{\circ} \mathrm{C}$. Values represent the means \pm standard errors $(n=5)$.

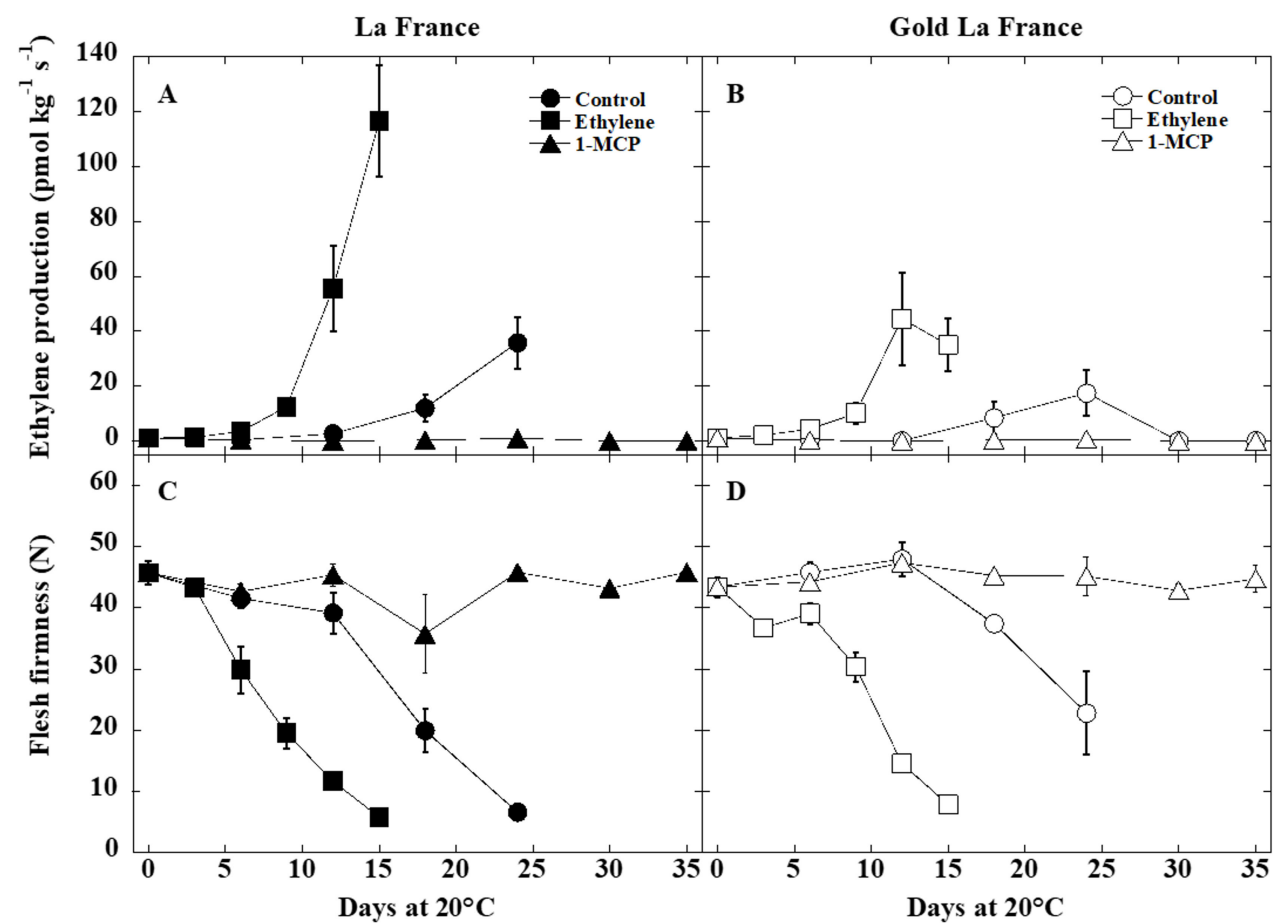

Figure 2. Changes in the ethylene production (A,B) and flesh firmness (C,D) of 'LaFrance' and 'Gold La France' fruit treated with ethylene and $1-\mathrm{MCP}$ during ripening at $20^{\circ} \mathrm{C}$. Values are means \pm standard errors $(n=5)$. 


\subsection{Color and Pigment Changes}

The color of 'Gorham' pears changed from green at harvest to yellow at the full ripe stage (Figure 3). That of its russeted sport 'Grand Champion' also changed and developed a light russet during ripening. In contrast, the colors of 'La France' and its russeted sport 'Gold La France' changed little during ripening. Fruit treated with ethylene changed to the same appearance as their wild-types during ripening; 'Gorham' and 'Grand Champion' turned yellow and light russet, respectively.

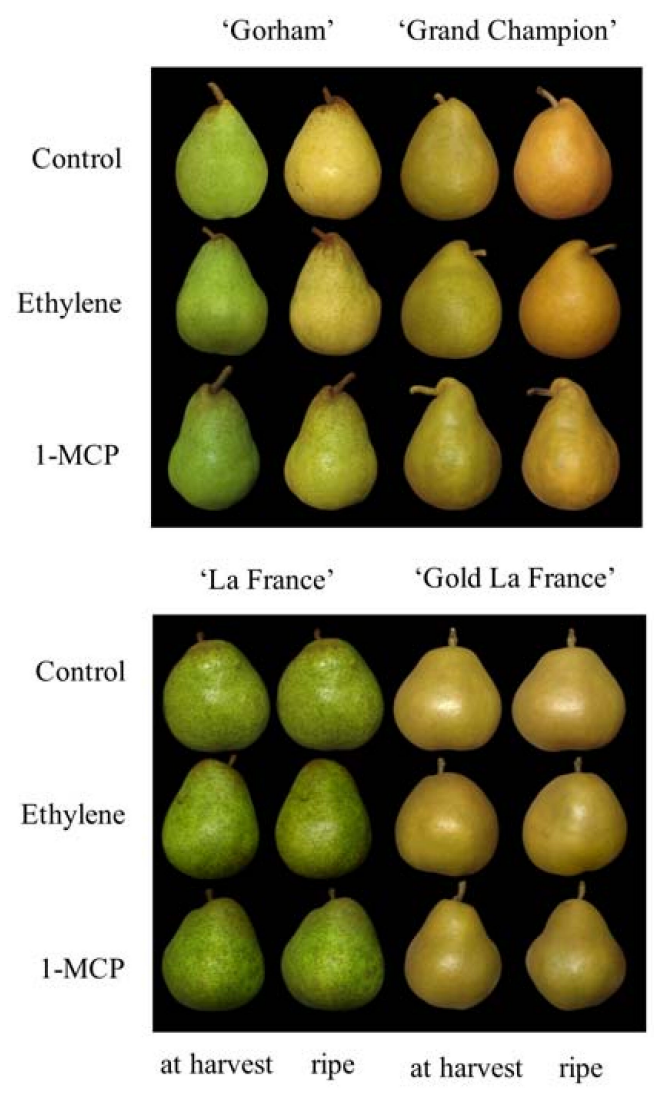

Figure 3. Fruit appearance of 'Gorham', 'Grand Champion', 'La France', and 'Gold La France' pears treated with ethylene and 1-MCP during ripening at $20^{\circ} \mathrm{C}$.

Chlorophyll concentration decreased after harvest in the control 'Gorham' pears (Figure 4). The chlorophyll level at harvest in 'Grand Champion' russet pears was slightly higher than that of 'Gorham' pears and decreased during ripening in the same pattern as 'Gorham' pears. Carotenoid concentration gradually decreased during ripening in both 'Gorham' and 'Grand Champion' pears.

Ethylene treatment did not stimulate chlorophyll degradation in 'Gorham' or 'Grand Champion' pears. In contrast, 1-MCP treatment suppressed chlorophyll degradation in both cultivars. This suppression was not complete; thus, chlorophyll concentration gradually decreased after day four, even in fruit treated with 1-MCP. However, the chlorophyll level on day 24 was significantly higher than those in the control and ethylene-treated fruits at the full ripe stage.

The chlorophyll concentration of 'La France' pears did not change for the first 12 days and then gradually decreased (Figure 5). However, the chlorophyll level on day 24 was significantly higher than those of 'Gorham' and 'Grand Champion' pears at the full ripe stage. The carotenoid concentration decreased slightly during ripening. Chlorophyll and carotenoid levels in 'Gold La France' did not change throughout the experimental period. Ethylene and 1-MCP treatments did not affect chlorophyll or carotenoid concentrations in 'La France' and 'Gold La France' pears. 


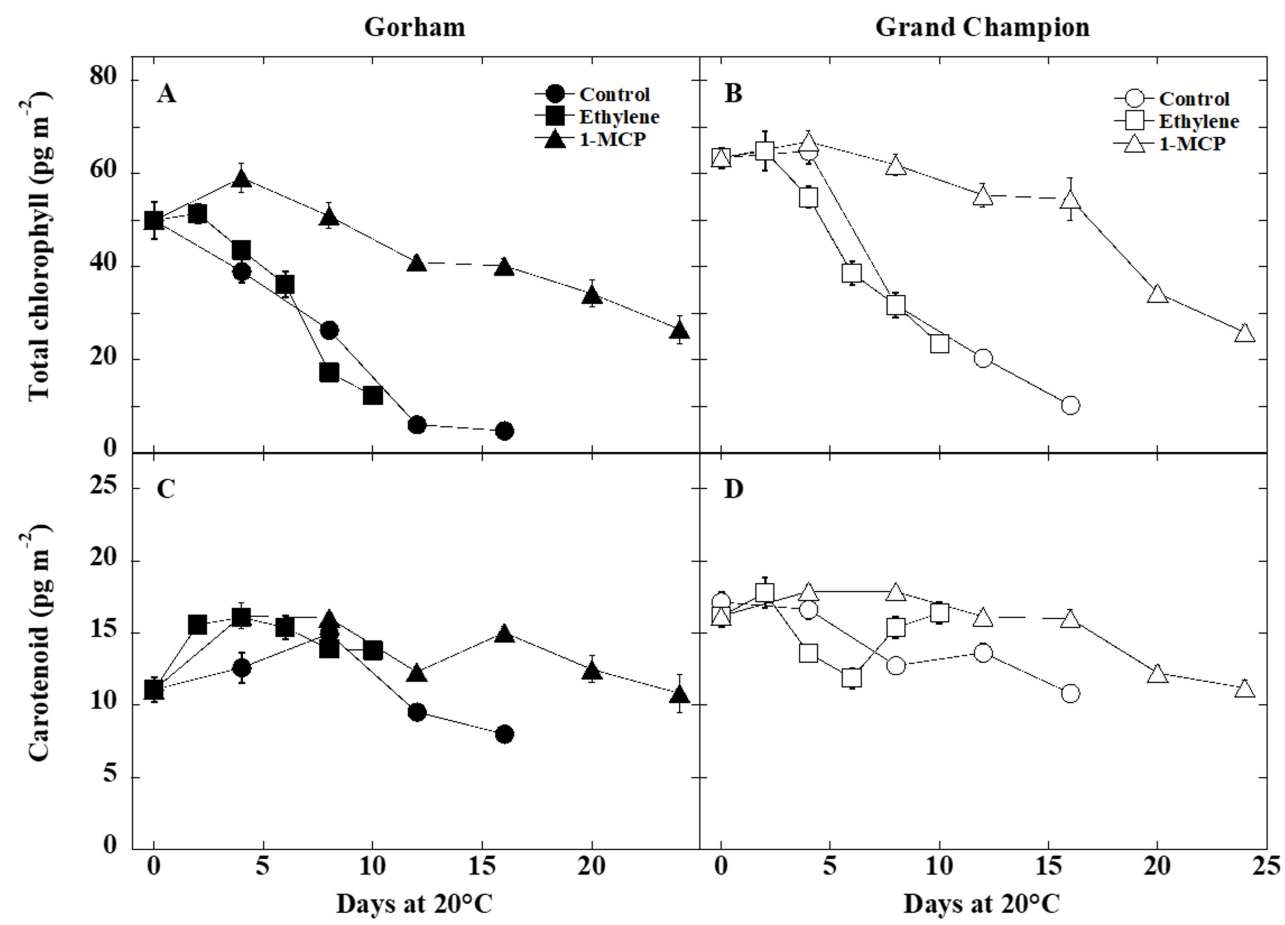

Figure 4. Changes in total chlorophyll $(\mathbf{A}, \mathbf{B})$ and carotenoid $(\mathbf{C}, \mathbf{D})$ concentration of 'Gorham' and 'Grand Champion' fruit treated with ethylene and 1-MCP during ripening at $20^{\circ} \mathrm{C}$. Values represent the means \pm standard errors $(n=5)$.

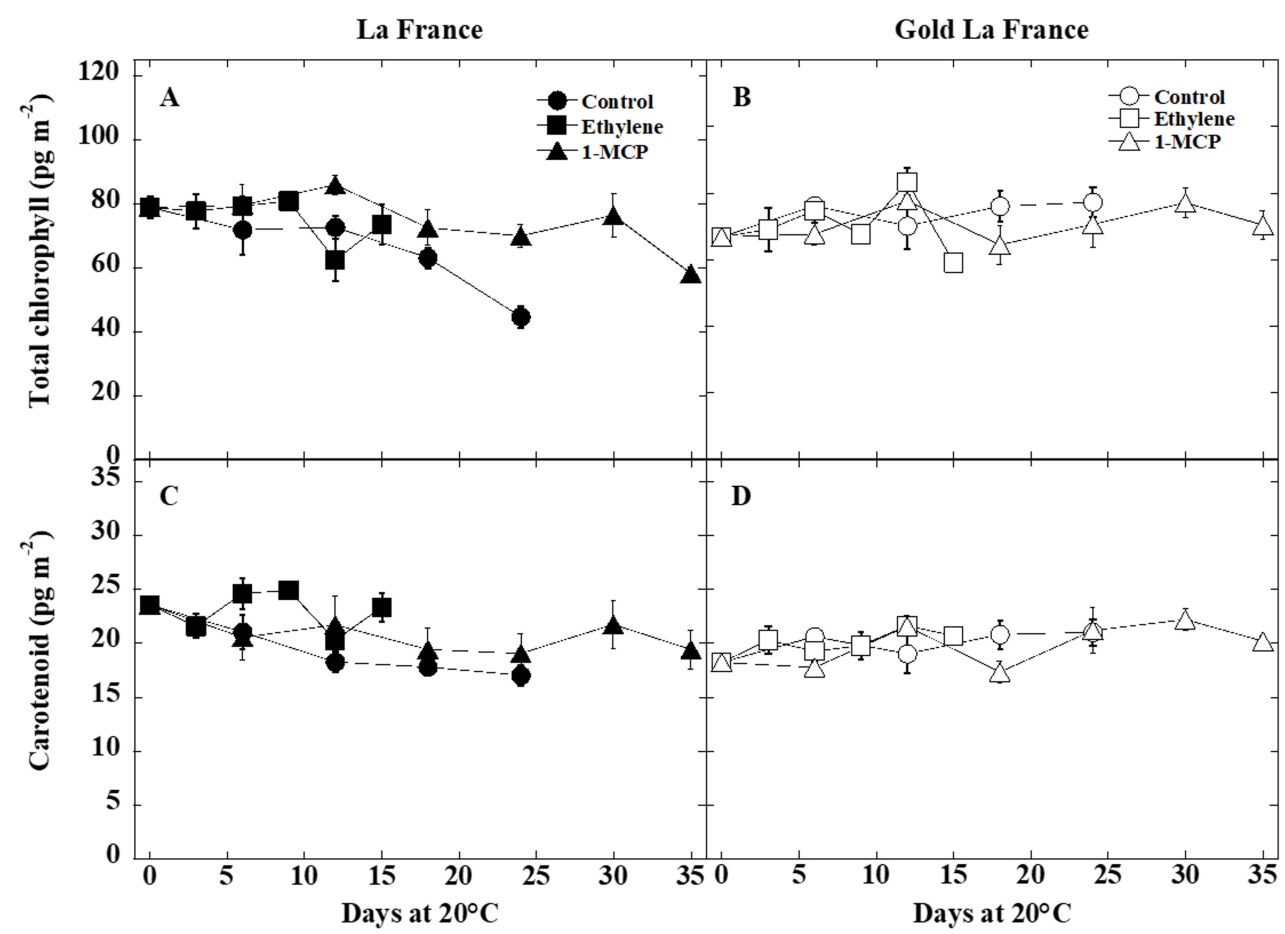

Figure 5. Changes in total chlorophyll (A,B) and carotenoid (C,D) concentration of 'LaFrance' and 'Gold La France' fruit treated with ethylene and 1-MCP during ripening at $20^{\circ} \mathrm{C}$. Values represent the means \pm standard errors $(n=5)$. 


\subsection{Chlorophyll-Degradation-Related Gene Expression}

The relative expressions of CLH1 and PPH genes in 'Gorham' and 'Grand Champion' control fruits decreased during ripening, although the transcription level of the $P P H$ gene in 'Grand Champion' transiently increased on day four (Figure 6A,B,G,H). The expression of both genes in 'Gorham' and 'Grand Champion' pears treated with ethylene peaked on days two and four, respectively. 1-MCP treatment suppressed or delayed a decrease in the expression levels of CLH1 and PPH genes in both cultivars. Relative expression of the $P A O$ gene increased after harvest and peaked on day four in both 'Gorham' and 'Grand Champion' pears (Figure 6C,I). The expression of $P A O$ also increased in fruits treated with ethylene and 1-MCP.

The relative expression of $N Y C 1$ increased after harvest in 'Gorham' and 'Grand Champion' pears (Figure 6D,J). These expression levels tended to increase during ethylene treatment and decrease during 1-MCP treatment. The expression of NOL showed the same pattern as that of the PAO gene, increasing after harvest and peaking on day four in both 'Gorham' and 'Grand Champion' pears (Figure 6E,K). Expression increased in fruits treated with ethylene and 1-MCP as observed with the PAO gene. The expression of SGR increased in 'Gorham' and 'Grand Champion' pears (Figure 6F,L). Expression levels were accelerated by ethylene treatment, and significantly suppressed by 1-MCP treatment.

In 'La France' and 'Gold La France' pears, the relative expression levels of CLH1 and PPH decreased during ripening, as in 'Gorham' and 'Grand Champion' pears (Figure 7A,B,G,H). Ethylene and MCP-1 treatments advanced and delayed the decreasing rate of those expressions, respectively. $P A O$ expression of the control 'La France' and 'Gold La France' pears increased after harvest, peaked on day six, and then rapidly decreased (Figure 7C,I). PAO expression tended to decrease during ethylene treatment and increase during $1-\mathrm{MCP}$ treatment.

The relative expression of NYC1 in 'La France' and 'Gold La France' pears increased after harvest, peaked on day six, and then decreased (Figure 7D,J). Ethylene and 1-MCP treatments did not significantly affect the expression in both cultivars. NOL gene expression in the control fruit gradually decreased during ripening (Figure $7 \mathrm{E}, \mathrm{K}$ ). Only a minor difference in mRNA levels was observed between the treatments. The relative expression of SGR in the control fruit of 'La France' and 'Gold La France' pears increased during ripening (Figure 7F,L). These expressions were accelerated by ethylene treatment while being significantly suppressed by 1-MCP treatment, as was observed with the 'Gorham' and 'Grand Champion' pears. 


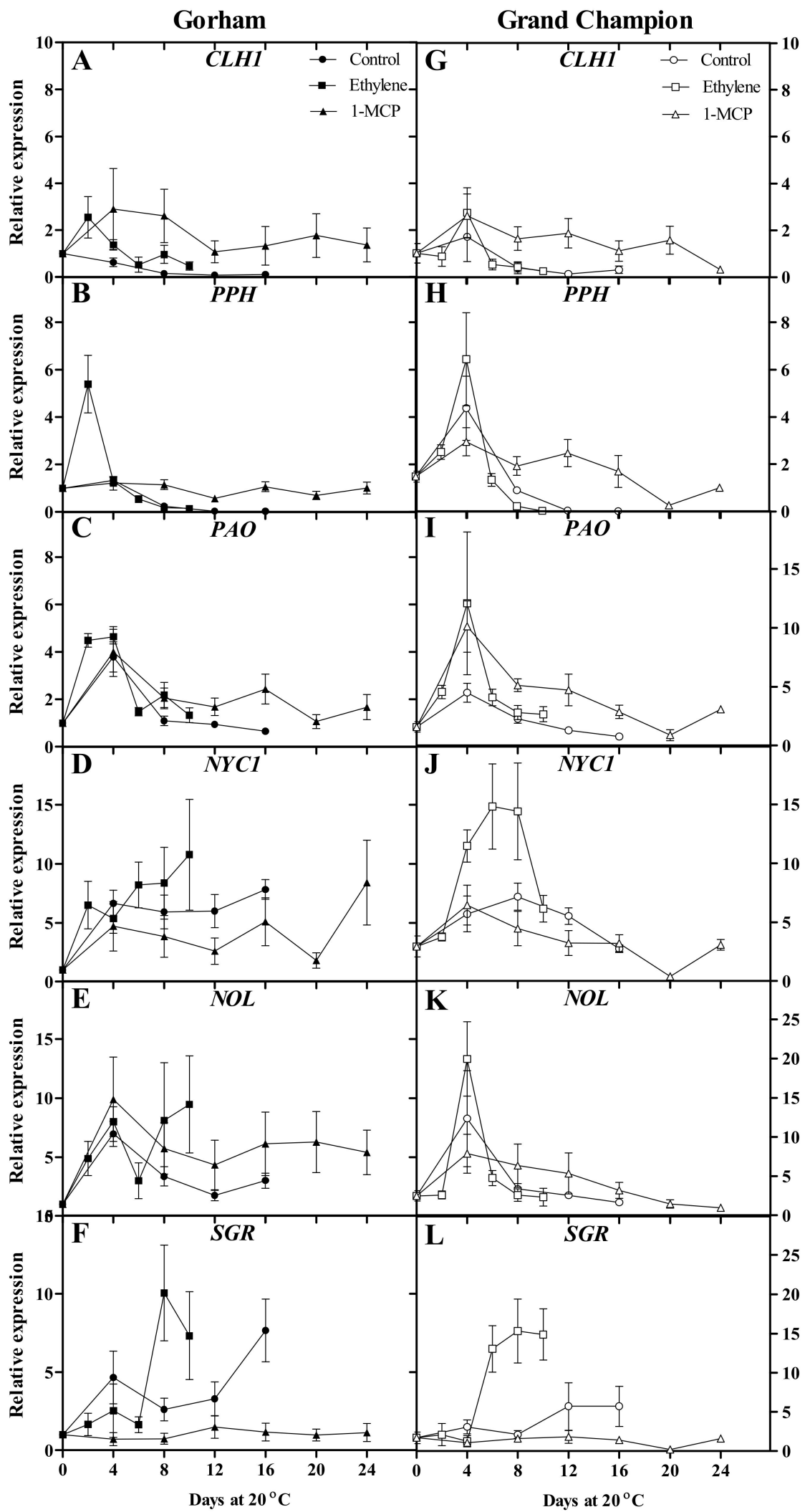

Figure 6. Relative expression of CLH1 (A,G), PPH (B,H), PAO (C,I), NYC1 (D,J), NOL (E,K) and SGR1 $(\mathbf{F}, \mathbf{L})$ in 'Gorham' and 'Grand Champion' fruit treated with ethylene and 1-MCP during ripening at $20{ }^{\circ} \mathrm{C}$. 


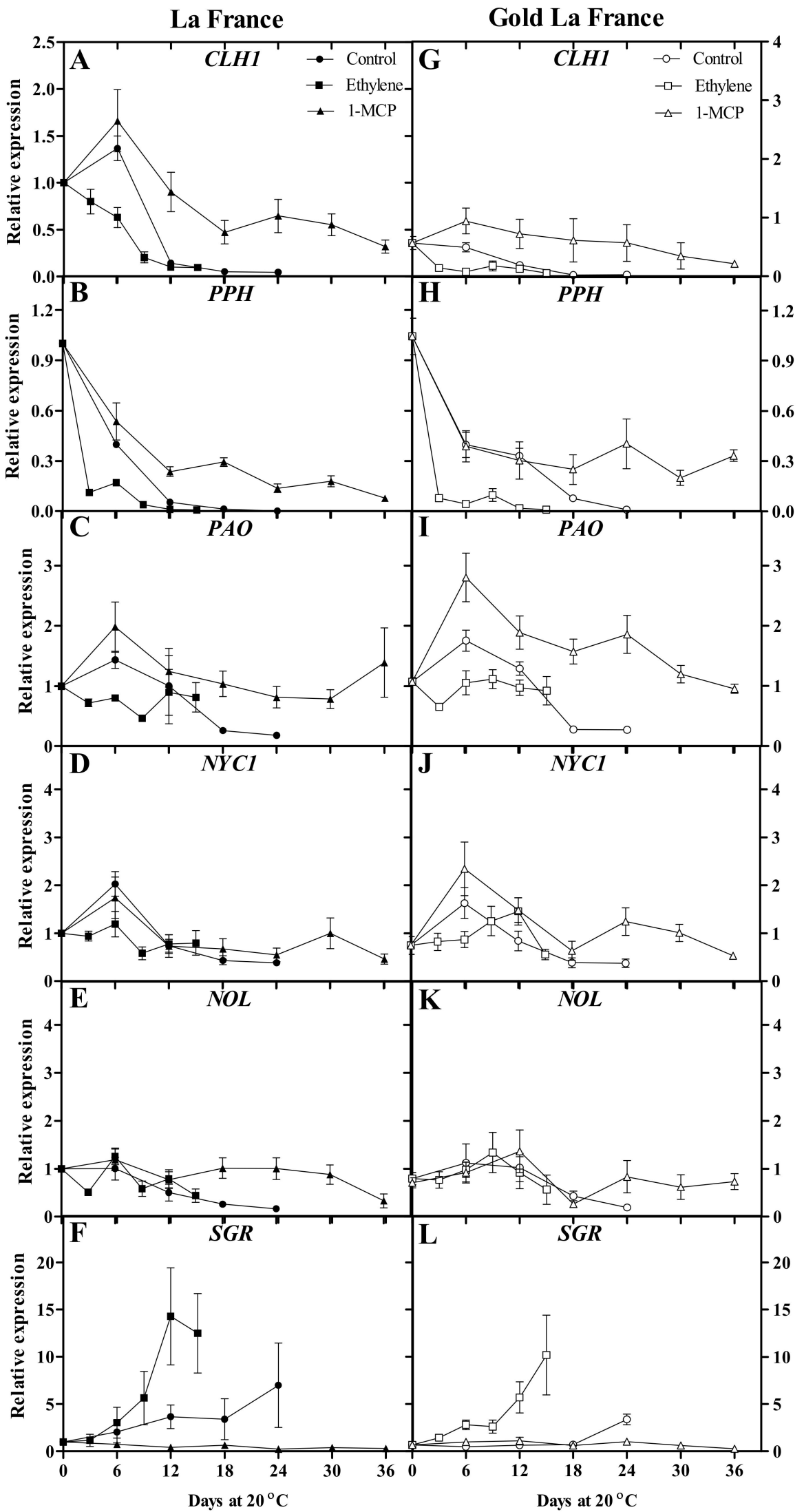

Figure 7. Relative expression of CLH1 (A,G), PPH (B,H), PAO (C,I), NYC1 (D,J), NOL (E,K) and SGR1 $(\mathbf{F}, \mathrm{L})$ in 'LaFrance' and 'Gold La France' fruit treated with ethylene and 1-MCP during ripening at $20{ }^{\circ} \mathrm{C}$. 


\section{Discussion}

\subsection{Ethylene Production and Fruit Softening}

The decrease of firmness in both green and russet pears corresponded with an increase in ethylene production. Interestingly, fruit softening tended to be delayed in 'Grand Champion' and 'Gold La France' russet pears compared with their wild-types, 'Gorham' and 'La France'. The delay in fruit softening correlated with late ethylene production in both russet cultivars. The accumulation of suberin, cutin, and wax on the surface of sand pear russet pericarps affected transpiration rate [9]. This may also affect ripening rates.

Ethylene has been reported to promote the ripening of climacteric fruit such as kiwifruit and bananas $[29,30]$. Our study showed that exogenous ethylene stimulated fruit ripening not only in green pears ('Gorham' and 'La France') but also russet pears ('Grand Champion' and 'Gold La France'). Conversely, the ethylene inhibitor 1-MCP strongly suppressed ethylene production in all of the examined pear cultivars. Low ethylene production is related to the suppression of fruit softening. Interestingly, fruit softening was completely suppressed by 1-MCP treatment in 'La France' and 'Gold La France' pears, while the suppression was partial in 'Gorham' and 'Grand Champion' pears. The effectiveness of 1-MCP application depends on many factors, such as the cultivar, fruit maturity at harvest, storage conditions, and duration of the treatment [31,32]. However, it is possible that there are two types of fruit softening: ethylene-dependent and ethylene-independent. Pech et al. [33] reviewed ethylene-dependent and independent regulation of ripening pathways in melon fruit. Antisense 1-aminocyclopropane-1-calboxylic acid oxidase melons exhibited a strong reduction in softening, but significant residual softening still persisted, indicating the presence of an ethylene-independent component in flesh softening [34]. In contrast, 1-MCP caused total inhibition of softening in pear fruit [35]. They used 'La France' pears for their experiment. We confirmed that the softening of this cultivar was completely suppressed by $1-\mathrm{MCP}$ treatment. These results showed that there was a cultivar difference in their response to 1-MCP in pear fruit.

\subsection{Fruit Color and Pigment Changes}

Variations in the color and appearance of fruit skin depend on the concentrations of pigments such as chlorophylls and carotenoids. In the present study, green 'Gorham' pears turned yellow during ripening. In this cultivar, chlorophyll concentration decreased after harvest. Carotenoid concentration did not increase during ripening, indicating that the development of yellow color in green pears results from the masking of carotenoids with chlorophyll at harvest and subsequent unmasking by chlorophyll degradation, as reported in the fruit or leaves of various plants, including pears $[1,2]$. Another green pear, 'La France', accounts for $\sim 70 \%$ of the pear production in Japan. This cultivar remains green even when fully ripe [3]. In the present study, we confirmed that the chlorophyll level on day 24 was significantly higher than those of 'Gorham' and 'Grand Champion' pears at the full ripe stage.

Chlorophyll accumulated in both russet pears, 'Grand Champion' and 'Gold La France', indicating that they were masked by russet. Surprisingly, their chlorophyll levels at harvest were comparable to those of the green pears. The chlorophyll level in 'Grand Champion' russet pears decreased during ripening. In this cultivar, carotenoid concentration also gradually decreased during ripening. These changes in pigment concentration in the russeted peel of 'Grand Champion' pears were the same as observed with 'Gorham' pear during ripening. The color of 'Grand Champion' pears turned from dark russet to light russet. This suggested that the color changes in russet skin may be correlated with chlorophyll concentration. Although the green exocarp of russet fruit is covered with a cork layer and appears brown, color changes via the chlorophyll degradation pathway occurred in the same manner as yellowing in green fruit. It has been reported that color changes in the russeted exocarp of potatoes corresponded with a variation in chlorophyll levels [36]. In another russet cultivar, 'Gold La 
France', the fruit color remained unchanged during ripening. These results suggest that the pigment concentrations of russet mutant pears follow those of their corresponding wild types.

Previous studies suggested that exogenous ethylene or endogenous ethylene accelerated chlorophyll breakdown in fruit peel $[37,38]$, which could be suppressed by the application of 1-MCP [26,32]. Even in citrus fruits, which are classified as non-climacteric fruits, the role of ethylene is well-established in chlorophyll breakdown during fruit color-break [37]. In the present study, 1-MCP treatments suppressed chlorophyll degradation in all cultivars. However, this suppression was not complete in 'Gorham' and 'Grand Champion' pears and chlorophyll concentrations gradually decreased after day four, even in fruits treated with 1-MCP. It is possible that there are ethylene-dependent and ethylene-independent regulatory pathways for chlorophyll degradation, although chlorophyll degradation has been classified as an ethylene-dependent process in melon fruit [33]. It was reported that the effect of 1-MCP on ripening parameters such as starch degradation, sugar accumulation, and preservation of titratable acidity, is not as dramatic as its effect on firmness [39,40]. Mier et al. [41] also suggest there are several parameters used as physiological measures of ripeness or maturity that are not tightly linked with ethylene biology. In contrast 'La France' and 'Gold La France' pears reached edible phases without the loss of chlorophyll. In these cultivars, ethylene or 1-MCP did not affect color or pigment changes.

\subsection{Chlorophyll-Degradation-Related Genes}

The changes in the relative expression of chlorophyll-degradation-related genes in the russet mutant pears ('Grand Champion and 'Gold La France') were similar to those of their wild-type analogs ('Gorham' and 'La France'). This was as expected because the chlorophyll concentrations of russet mutant pears followed those of their corresponding wild-types. The relative expression levels of CLH1, $P P H, P A O, N Y C 1$, and NOL in 'Gorham' and 'Grand Champion' pears seemed higher compared to those in the stay-green cultivar ('La France') and its mutant ('Gold La France'). These results support those of a prior report that the transcription levels of CLH1, PAO, NYC, and NOL genes in 'Le Lectier' yellowing pears were higher than those in 'La France' pears [3].

In this study, ethylene and 1-MCP were applied to explore the role of ethylene on the expression of chlorophyll degradation genes. 1-MCP can reportedly delay chlorophyll degradation by inhibiting ethylene production and suppressing $P A O, N Y C, N O L$, and SGR gene expression in Chinese pears [26]. In 'Gorham' and 'Grand Champion' pears, the transcription levels of such genes were stimulated by ethylene treatments. However, the effects of 1-MCP treatment on the expressions of PAO, NYC, and NOL genes were unclear. Thus, it is difficult to determine whether these are ethylene-dependent genes. Only the SGR gene was clearly upregulated by ethylene and suppressed by 1-MCP, indicating that this gene was ethylene-dependent. Interestingly, these effects were observed not only in 'Gorham' and 'Grand Champion' pears but also in the stay-green cultivars, 'La France' and 'Gold La France'. SGR has been shown to physically interact with known chlorophyll catabolic enzymes (i.e., NYC1, NOL, PPH, PAO, and RCCR), and it also interacts with LHCII subunits [42]. A deficiency of SGR in tomato and red pepper caused a stay-green phenotype in leaves and fruit $[43,44]$. These results suggest that $S G R$ may be an important gene in the chlorophyll degradation pathway of pear fruit. The reason that chlorophyll degradation does not occur in 'La France' and 'Gold La France' pears with normal expression levels of the $S G R$ gene remains unclear.

\section{Conclusions}

Russet development and pigment change on peels determine most part of the appearance of European pears. In the present study, russet was indicated to delay a burst in ethylene production during ripening process and the concomitant fruit softening and chlorophyll degradation, but not to affect the ethylene sensitivity and the pigment changes itself. The Stay green-1 gene appeared to be related to chlorophyll degradation in response to ethylene. It is expected that future studies will clarify the molecular mechanism underlying the color variation of European pears 
Author Contributions: H.M. conceived and designed the experiments; N.C. and D.M. performed the experiments and wrote the paper; all authors analyzed the data.

Funding: This work was supported by JSPS KAKENHI Grant Number JP16H04871.

Conflicts of Interest: The authors declare no conflict of interest.

\section{References}

1. Gross, J. Chlorophyll and carotenoids in the peel of 2 pear cultivars. Gartenbauwissenschaft 1984, 49, $128-131$. [CrossRef]

2. Matile, P.; Hortensteiner, S.; Thomas, H. Chlorophyll degradation. Annu. Rev. Plant Physiol. Plant Mol. Biol. 1999, 50, 67-95. [CrossRef] [PubMed]

3. Charoenchongsuk, N.; Ikeda, K.; Itai, A.; Oikawa, A.; Murayama, H. Comparison of the expression of chlorophyll-degradation-related genes during ripening between stay-green and yellow-pear cultivars. Sci. Hortic. 2015, 181, 89-94. [CrossRef]

4. Soler, M.; Serra, O.; Molinas, M.; Huguet, G.; Fluch, S.; Figueras, M. A genomic approach to suberin biosynthesis and cork differentiation. Plant Physiol. 2007, 144, 419-431. [CrossRef] [PubMed]

5. Pollard, M.; Beisson, F.; Li, Y.H.; Ohlrogge, J.B. Building lipid barriers: Biosynthesis of cutin and suberin. Trends Plant Sci. 2008, 13, 236-246. [CrossRef] [PubMed]

6. Schreiber, L.; Franke, R.; Hartmann, K. Wax and suberin development of native and wound periderm of potato (Solanum tuberosum L.) and its relation to peridermal transpiration. Planta 2005, 220, 520-530. [CrossRef] [PubMed]

7. Kikuti, A. On the origin of Japanese pear and the inheritance of the skin colours of their fruits. Jpn. J. Genet. 1924, 3, 1-21. [CrossRef]

8. Inoue, E.; Kasumi, M.; Sakuma, F.; Anzai, H.; Amano, K.; Hara, H. Identification of RAPD marker linked to fruit skin color in Japanese pear (Pyrus pyrifolia Nakai). Sci. Hortic. 2006, 107, 254-258. [CrossRef]

9. Wang, Y.Z.; Dai, M.S.; Zhang, S.J.; Shi, Z.B. Exploring Candidate genes for pericarp russet pigmentation of sand pear (Pyrus pyrifolia) via RNA-seq data in two genotypes contrasting for pericarp color. PLoS ONE 2014, 9, e83675. [CrossRef] [PubMed]

10. Wang, Y.Z.; Zhang, S.J.; Dai, M.S.; Shi, Z.B. Pigmentation in sand pear (Pyrus pyrifolia) fruit: Biochemical characterization, gene discovery and expression analysis with exocarp pigmentation mutant. Plant Mol. Biol. 2014, 85, 123-134. [CrossRef] [PubMed]

11. Sugar, D.; Basile, S.R. Color and russet variation among selections of 'Bosc' pear. J. Am. Pomol. Soc. 2008, $62,77-81$.

12. Barcelo-Vidal, C.; Bonany, J.; Martin-Fernandez, J.A.; Carbo, J. Modelling of weather parameters to predict russet on 'Golden Delicious' apple. J. Hortic. Sci. Biotechnol. 2013, 88, 624-630. [CrossRef]

13. Heidenreich, M.C.M.; CorralGarcia, M.R.; Momol, E.A.; Burr, T.J. Russet of apple fruit caused by Aureobasidium pullulans and Rhodotorula glutinis. Plant Dis. 1997, 81, 337-342. [CrossRef]

14. Spotts, R.A.; Cervantes, L.A. Involvement of Aureobasidium pullulans and Rhodotorula glutinis in russet of d'Anjou pear fruit. Plant Dis. 2002, 86, 625-628. [CrossRef]

15. Looney, N.E.; Granger, R.L.; Chu, C.L.; McArtney, S.J.; Mander, L.N.; Pharis, R.P. Influences of gibberellins $\mathrm{A}_{4}, \mathrm{~A}_{4+7}$, and $\mathrm{A}_{4}+\mathrm{Iso}-\mathrm{A}_{7}$ on apple fruit-quality and tree productivity. I. Effects on fruit russet and tree yield components. J. Hortic. Sci. 1992, 67, 613-618. [CrossRef]

16. Sugar, D.; Powers, K.A.; Basile, S.R. Mancozeb and kaolin applications can reduce russet of 'Comice' pear. HortTechnology 2005, 15, 272-275.

17. Barry, C.S.; Giovannoni, J.J. Ethylene and fruit ripening. J. Plant Growth Regul. 2007, 26, 143-159. [CrossRef]

18. Sisler, E.C.; Serek, M. Inhibitors of ethylene responses in plants at the receptor level: Recent developments. Physiol. Plant 1997, 100, 577-582. [CrossRef]

19. Blankenship, S.M.; Dole, J.M. 1-methylcyclopropene: A review. Postharvest Biol. Technol. 2003, $28,1-25$. [CrossRef]

20. Watkins, C.B. The use of 1-methylcyclopropene (1-MCP) on fruits and vegetables. Biotechnol. Adv. 2006, 24, 389-409. [CrossRef] [PubMed]

21. Isidoro, N.; Almeida, D.P.F. Alpha-farnesene, conjugated trienols, and superficial scald in 'Rocha' pear as affected by 1-methylcyclopropene and diphenylarnine. Postharvest Biol. Technol. 2003, 42, 49-56. [CrossRef] 
22. Xie, X.; Zhao, J.; Wang, Y. Initiation of ripening capacity in 1-MCP treated green and red 'Anjou' pears and associated expression of genes related to ethylene biosynthesis and perception following cold storage and post-storage ethylene conditioning. Postharvest Biol. Technol. 2016, 111, 140-149. [CrossRef]

23. Zhi, H.; Dong, Y. Effect of 1-methylcyclopropene on superficial scald associated with ethylene production, $\alpha$-farnesene catabolism, and antioxidant system of over-mature 'd'Anjou' pears after long-term storage. Food Bioprocess Technol. 2018, 11, 1775-1786. [CrossRef]

24. Bower, J.H.; Blasi, W.V.; Mitcham, E.J. Effect of ethylene in the storage environment on quality of 'Bartlett pears'. Postharvest Biol. Technol. 2003, 28, 371-379. [CrossRef]

25. Cheng, Y.D.; Guan, J.F. Involvement of pheophytinase in ethylene-mediated chlorophyll degradation in the peel of harvested 'Yali' pear. J. Plant Growth Regul. 2014, 33, 364-372. [CrossRef]

26. Cheng, Y.D.; Dong, Y.; Yan, H.B.; Ge, W.Y.; Shen, C.G.; Guan, J.F.; Liu, L.Q.; Zhang, Y.Y. Effects of 1-MCP on chlorophyll degradation pathway-associated genes expression and chloroplast ultrastructure during the peel yellowing of Chinese pear fruits in storage. Food Chem. 2012, 135, 415-422. [CrossRef] [PubMed]

27. Arnon, D.I. Copper enzymes in isolated chloroplasts. Polyphenoloxydase in Beta vulgaris. Plant Physiol. 1949, 24, 1-15. [CrossRef] [PubMed]

28. Livak, K.J.; Schmittgen, T.D. Analysis of relative gene expression data using real-time quantitative PCR and the $2^{-\Delta \Delta C T}$ method. Methods 2001, 25, 402-408. [CrossRef] [PubMed]

29. Shan, W.; Kuang, J.F.; Chen, L.; Xie, H.; Peng, H.H.; Xiao, Y.Y.; Li, X.P.; Chen, W.X.; He, Q.G.; Chen, J.Y.; et al. Molecular characterization of banana NAC transcription factors and their interactions with ethylene signalling component EIL during fruit ripening. J. Exp. Bot. 2012, 63, 5171-5187. [CrossRef] [PubMed]

30. Yin, X.R.; Chen, K.S.; Allan, A.C.; Wu, R.M.; Zhang, B.; Lallu, N.; Ferguson, I.B. Ethylene-induced modulation of genes associated with the ethylene signalling pathway in ripening kiwifruit. J. Exp. Bot. 2008, 59, 2097-2108. [CrossRef] [PubMed]

31. Gamrasni, D.; Ben-Arie, R.; Goldway, M. 1-Methylcyclopropene (1-MCP) application to Spadona pears at different stages of ripening to maximize fruit quality after storage. Postharvest Biol. Technol. 2010, 58, 104-112. [CrossRef]

32. Villalobos-Acuna, M.G.; Biasi, W.V.; Flores, S.; Jiang, C.Z.; Reid, M.S.; Willits, N.H.; Mitcham, E.J. Effect of maturity and cold storage on ethylene biosynthesis and ripening in 'Bartlett' pears treated after harvest with 1-MCP. Postharvest Biol. Technol. 2011, 59, 1-9. [CrossRef]

33. Pech, J.C.; Bouzayen, M.; Latché, A. Climacteric fruit ripening: Ethylene-dependent and independent regulation of ripening pathways in melon fruit. Plant Sci. 2008, 175, 114-120. [CrossRef]

34. Guis, M.; Botondi, R.; Ben-Amor, M.; Ayub, R.; Bouzayen, M.; Pech, J.-C.; Latché, A. Ripening-associated biochemical traits of Cantaloupe Charentais melons expressing an antisense ACC oxidase transgene. J. Am. Soc. Hortic. Sci. 1997, 122, 748-751.

35. Hiwasa, K.; Kinugasa, Y.; Amano, S.; Hashimoto, A.; Nakano, R.; Inaba, A.; Kubo, Y. Ethylene is required for both the initiation and progression of softening in pear (Pyrus communis L.) fruit. J. Exp. Bot. 2003, 54, 771-779. [CrossRef] [PubMed]

36. Grunenfelder, L.; Hiller, L.K.; Knowles, N.R. Color indices for the assessment of chlorophyll development and greening of fresh market potatoes. Postharvest Biol. Technol. 2006, 40, 73-81. [CrossRef]

37. Porat, R.; Weiss, B.; Cohen, L.; Daus, A.; Goren, R.; Droby, S. Effects of ethylene and 1-methylcyclopropene on the postharvest qualities of 'Shamouti' oranges. Postharvest Biol. Technol. 1999, 15, 155-163. [CrossRef]

38. Trebitsh, T.; Goldschmidt, E.E.; Riov, J. Ethylene induces de-novo synthesis of chlorophyllase, a chlorophyll degrading enzyme, in citrus-fruit peel. Proc. Natl. Acad. Sci. USA 1993, 90, 9441-9445. [CrossRef] [PubMed]

39. Fan, X.; Blankenship, S.M.; Mattheis, J. 1-Methylcyclopropene inhibits apple ripening. J. Am. Soc. Hortic. Sci. 1999, 124, 690-695.

40. Watkins, C.B.; Nock, J.F.; Whitaker, B.D. Responses of early, mid and late season apple cultivars to postharvest application of 1-methylcyclopropene (1-MCP) under air and controlled atmosphere storage conditions. Postharvest Biol. Technol. 2000, 19, 17-23. [CrossRef]

41. Mir, N.A.; Curell, E.; Khan, N.; Whitaker, M.; Beaudry, R.M. Harvest maturity, storage temperature, and 1-MCP application frequency alter firmness retention and chlorophyll fluorescence of 'Redchief Delicious' apples. J. Am. Soc. Hortic. Sci. 2001, 126, 618-624. 
42. Sakuraba, Y.; Schelbert, S.; Park, S.-Y.; Han, S.-H.; Lee, B.-D.; Andrès, C.B.; Kessler, F.; Hörtensteiner, S.; Paek, N.C. STAY-GREEN and chlorophyll catabolic enzymes interact at light-harvesting complex II for chlorophyll detoxification during leaf senescence in Arabidopsis. Plant Cell 2012, 24, 507-518. [CrossRef] [PubMed]

43. Barry, C.S.; McQuinn, R.P.; Chung, M.-Y.; Besuden, A.; Giovannoni, J.J. Amino Acid Substitutions in homologs of the STAY-GREEN protein are responsible for the green-flesh and chlorophyll retainer mutations of tomato and pepper. Plant Physiol. 2008, 147, 179-187. [CrossRef] [PubMed]

44. Borovsky, Y.; Paran, I. Chlorophyll breakdown during pepper fruit ripening in the chlorophyll retainer mutation is impaired at the homolog of the senescence-inducible stay-green gene. Theor. Appl. Genet. 2008, 117, 235-240. [CrossRef] [PubMed]

(C) 2018 by the authors. Licensee MDPI, Basel, Switzerland. This article is an open access article distributed under the terms and conditions of the Creative Commons Attribution (CC BY) license (http:/ / creativecommons.org/licenses/by/4.0/). 